\title{
Large Platelet Count
}

National Cancer Institute

\section{Source}

National Cancer Institute. Large Platelet Count. NCI Thesaurus. Code C74729.

The determination of the number of large platelets present in a sample. 